\title{
BIBLICAL INTERPRETATION IN ESTABLISHED BIBLE STUDY GROUPS: A CHRONICLE OF A REGIONAL RESEARCH PROJECT
}

\author{
Ernst M Conradie \\ Department of Religion and Theology, University of the Western Cape, \\ Hendrik L Bosman \\ Department of Old and New Testament, Stellenbosch University, \\ Louis C Jonker \\ Department of Old and New Testament, Stellenbosch University
}

\section{Informal discussions lead to cooperation in research}

During 1995 a number of Biblical scholars from the Universities of the Western Cape and Stellenbosch came together for some informal discussions on the interpretation of the Bible. With the occasional participation of scholars from other fields (e.g. Johan Degenaar and Paul Cilliers from Philosophy) topics such as "Multidimensional interpretation", "Textuality and Intertextuality" were discussed. From these informal discussions surfaced the desire to participate on a regional basis in a joint research project that would investigate the reading strategies people use when they read the Bible.

\section{A pilot project gets off the ground}

During 1996 several theologians from the Western Cape ${ }^{1}$ convened to discuss the viability of cooperative research on the notion of "reading strategies" in the context of established Bible study groups. Some preliminary questions had to be cleared out, such as the ultimate ownership of the project and what financial means would be sought. In the end it was decided to form a working group that would embark on a pilot project funded on an ad hoc basis through the University of Stellenbosch. It was also decided that postgraduate students would be involved to take responsibility for the administrative tasks.

A total of eight established Bible study groups ${ }^{2}$ in the Western Cape region were identified. Although the groups were selected from as many different backgrounds as possible (taking gender, race, class, age and ecclesial traditions into account), we did not claim that our selection was representative of any set of criteria. All eight groups were indeed established Bible study groups. Each group had its own history, ${ }^{3}$ group dynamics and main purpose for meeting. Four Biblical texts (i.e. Judges 9, Hosea 11, Mark 2, Romans 8) were identified. We also did not claim that these four texts were representative of anything, although certain aspects of these four texts prompted their selection (genre ${ }^{4}$ and canonical considerations were taken into account).

1. The following scholars took part in the initial discussions: Hendrik Bosman, Bernard Combrink, Louis Jonker (all from US); Ernst Conradie, Douglas Lawrie, Roger Arendse, Danie van Zyl (all from UWC); and Chuck Wanamaker (from UCT).

2. (i) UCT Administration Bible study group; (ii) DRC Ottery women's group; (iii) Sokhanya: Site B in Khayalitsha; (iv) Sokhanya: Cross Roads; (v) Bongweni-Mandalay group (vi) URC group in Jamestown near Stellenbosch; (vii) DRC Stellenbosch-Sentraal men's group; (viii) Philadelphia students' group in Stellenbosch.

3. The Jamestown group, for example, has a history going back for more than 50 years.

4. The following texts were selected: A fable (Judges 9), prophecy (Hosea 11), a miracle account (Mark 2) and an argumentative text (Romans 8). 
We decided that our empirical research would be done non-intrusively and nonparticipatory. Each of the eight groups was requested "to read the particular text in the way they normally read the Bible." Permission was asked to make a tape recording of each session. At this stage the purpose of the research project remained somewhat vague, i.e. to investigate the "reading strategies" used by various established Bible study groups in different contexts.

\section{Some basic problems}

Empirical Biblical hermeneutics is in many ways a new, emerging field of study. It was therefore necessary to raise some very basic questions from the outset. The following questions were, for example, identified:

- How can the process of text interpretation in Bible study groups be mapped or modelled?

- What are the interpretative interests that influence reading strategies in an established Bible study group?

- How can communication be facilitated between divergent readers in general and between professional (academic) readers and "ordinary readers" in particular?

\section{A project design emerged}

The following project design gradually emerged:

- A theoretical component that reflects on the modelling of Biblical interpretation;

- An empirical component that investigates the interpretation of the Bible within different reading/reader communities;

- An operational component that could develop a pedagogical instrument to facilitate adequacy in the context of group Bible study and that could design programmes for church leaders to sensitise them about the way reader communities interpret the Bible.

\section{Slow progress during 1997 and 1998}

During 1997 the pilot study made slow but steady progress due to the time consuming refinement of the project's theoretical framework. The concept of "interpretation" elicited, for example, considerable discussion. ${ }^{5}$ Aspects that play a role in Biblical interpretation such as the world behind the text, the text itself, the ecclesial tradition of interpretation, the contemporary context of interpretation, the process of theological appropriation in the Bible study group and the group dynamics of the groups were identified and discussed. A provisional descriptive and evaluative instrument was developed to describe and compare the interpretation / reading strategies employed by the eight Bible study groups. ${ }^{6}$ Certain provisional criteria for adequate interpretation were designed.

The pilot project eventually developed descriptive and evaluative tools on the basis of the following seven factors playing a role in group Bible studies:

1) The text itself;

2) The world-behind-the-text;

3) The history of interpretation in-front-of-the-text;

4) The spiral of appropriation and application;

5) The contemporary context(s) of the interpreter;

6) The possibility of ideological distortions from a world "below" each of these aspects;

7) The interaction and dynamics within the group. ${ }^{7}$

5. See the contribution by Lawrie elsewhere in this volume.

6. See the contributions by Jonker and Conradie \& Jonker elsewhere in this volume.

7. See the discussion by Conradie elsewhere in this volume. 
Some steady progress was also made on the empirical component of the project. Transcriptions were made of each of the recorded Bible studies. The transcriptions were discussed and analysed in some detail at regular meetings of the working group. At first, the various readings of the same text by the eight Bible study groups were compared with one another. When all the transcriptions became available, the interpretative strategies employed by each group were also discussed by analysing the different Bible studies of the same group. Each analysis was done on the basis of a close reading of the transcriptions. In addition, two Bible studies were recorded on video to augment the verbal transcriptions with visual impressions. This facilitated the observation of the dynamics within the particular groups - which could not be determined from the audio recordings. It also convinced the research group of the importance of various non-verbal aspects of Biblical interpretation in a group context. As a result, the need for video recordings was evident in the next phase of the project.

The above mentioned descriptive and evaluative instrument was used where appropriate to structure the discussions. At the same time, this instrument had to be refined on an ongoing basis. The analysis of each Bible study event illustrated the incredible complexity of Biblical interpretation. Through the ongoing empirical work more and more factors that influence group Bible study were identified and discussed. It became more than evident that our hermeneutical theories were scarcely able to do justice to the praxis of the Bible study groups.

Due to the study leave of several members of the research group during 1998, the anticipated conclusion of the pilot phase of the project was impeded.

\section{Consolidation during 1999}

During the first semester of 1999 the research group was able to consolidate and conclude the findings of the pilot project. The following decisions emerged from this process:

1) It was decided not to disseminate the results of the empirical component of the pilot project. Although the discussion of the various transcriptions proved to be rich and fascinating, few empirical conclusions could be drawn from the "thick descriptions" of the transcriptions. For example, conclusions concerning the relative influence of gender, race, class, age or ecclesial tradition on Biblical interpretation were clearly impossible and not particularly illuminating.

2) The empirical component of the pilot project therefore served the purpose of helping to refine the descriptive and evaluative instrument(s) that were developed in the theoretical component. This result remains rather ambiguous since the transcriptions clearly indicated that Bible study within a group context is an incredibly complex event that cannot be captured fully, even in the most sophisticated of theories.

The theoretical reflections on the process of Biblical interpretation in established Bible study groups is documented elsewhere in this volume. This represents some degree of consensus within the working group but it also indicates many unresolved issues, above all on the very meaning of the concept of "interpretation" itself. Lawrie, for example, prefers to distinguish the notion of "interpretation" from "reading" and "re-inscription". By contrast, Conradie uses "interpretation" in a comprehensive sense that includes many indirect and subconscious ways of appropriating texts. This also leads to differing ways of mapping the event of "interpretation." 


\section{A new project emerges}

On the basis of the experience gained from analysing the various transcriptions in the pilot project, a new empirical project was planned during the second semester of 1999. Funding for this new project was obtained from the National Research Foundation towards the end of 1999.

Through the pilot project a number of factors that influence group Bible study were identified. The purpose of the new project was to establish not only whether these factors play a role, but also in what way they influence group Bible study and how they do so in relation to one another.

Several research hypotheses were formulated in this regard by Conradie and Jonker. These hypotheses were derived from the analyses of the group Bible studies during the pilot project. These hypotheses did not necessarily articulate a consensus opinion within the research group. At best, it was able to draw on the theoretical work derived from the pilot project in order to test some of these theories empirically within the context of established Bible study groups.

The following hypotheses were formulated in the research proposal that was submitted to the National Research Foundation (the numbers in brackets refer to the factors influencing Biblical interpretation in the context of established Bible study groups as these were identified in the pilot project - see above):

- The interpretation and application of Biblical texts within a given contemporary context is strongly influenced by the dominant doctrinal keys $^{8}$ of the group. These doctrinal keys are derived from the ecclesial or theological tradition of the group. Most groups show a strong need for a confirmation and reassurance of the legitimacy of their doctrinal keys. [3]

8. Doctrinal keys are typically based on the dominant beliefs, doctrines, values, customs, and habits of interpretive communities. They are not directly derived from either the Biblical text or the contemporary world but are precisely the product of previous attempts to construct a relationship between text, tradition and context. They have a double function in theological interpretation. They provide a key to unlock both the meaning of the contemporary context and of the Biblical texts. They therefore (and simultaneously) enable an interpreter to establish a link between text and contemporary context. Doctrinal keys are not only employed to find similarities but to construct similarities, to make things similar (idem-facere), if necessary. The scope of such doctrinal keys is often quite comprehensive: they purport to provide a clue to the core meaning of the contemporary context as a whole and the Biblical text as a whole.

The following examples of such doctrinal keys may be listed here:

- The heart of the gospel is that sinners are justified by God's grace through faith (Lutheran churches).

- The message of the Bible is that God's just reign has to be established throughout the world (Reformed churches).

- The Bible contains the story of God's acts of salvation and liberation from poverty and oppression (liberation theology).

- The good news of the gospel becomes concretised when evil spirits are exorcised through the power of God's Spirit (African Pentecostal churches).

- The church of Christ is called to spread the gospel through its bishops, through the celebration of the Eucharist, through charity and through preaching (Roman Catholic churches).

- "Jesus loves me this I know, for the Bible tells me so." (Pietism).

- The resurrection of Christ indicates that the power of death and destruction has been conquered (Eastern Orthodox churches).

- The message of the Bible is that you have to accept Jesus as your personal Saviour (Evangelical movements).

- The Bible provides us with words of wisdom; Jesus sets an appropriate example for others to follow (Modern liberalism).

- The Bible tells the story of the powerful work of the Holy Spirit - in the history of Israel, in the life of Jesus, in the early church and also in the many gifts of the Spirit today (Charismatic churches). 
- Various strategies may be used for a relatively direct application of a text [4], e.g.

- The identification of a-temporal doctrinal or moral rules in the text ("We must remember that ..."; "I learned today that ...");

- The identification of inspiring analogies between the situation described in the text and the group's own context ("I also experience ... in my life.");

- The search for a contemporary fulfilment of God's promises embedded in the text (God is encouraging / challenging / warning / reassuring me that ...);

- The search for a confirmation of the beliefs, values and practices of the group in the text (by quoting proof texts).

Furthermore, the events within which the reading of a Biblical text are embedded (where the interpretation / application arrived at through the Bible Study is presumably expressed) are strongly influenced by the specific purpose for which the Bible Study group meets regularly (e.g. a support group, spiritual growth through an integration of faith commitments, a deepening of knowledge and insight, encouragement for service, an opportunity for worship and experiencing God's presence), and only indirectly by the reading of the text itself. ${ }^{9}$

- Features in the surface structure of the text are predominantly interpreted in terms of the dominant heuristic keys of the group and not within the parameters of the text itself. The actual reading of the text therefore serves to reinforce, clarify, elucidate and refine the existing beliefs, values and practices of the group. Groups tend to avoid the unfamiliar, the problematic, the contradictory, the ambiguous, any signs of "otherness" or particularity. As a result, many interpretations of a text appear highly generalised. Particular texts are merely regarded as examples of well-known types. In this way, the expectations of the group are almost always confirmed. [1]

- Bible Study groups are often less interested in historical questions about "what the text has meant" (and thus the historical background of the text) and more in "what the text means" within their own context. There is a tendency to assimilate the "world" of the Bible (its narratives, characters, topography, symbols, themes, etc) within the group's own interpretative world. The larger frame within which a text is interpreted is usually not historical but doctrinal or moral (laws, principles). Often, the text is simply regarded as an example of Christian life. [2]

- Contextual factors such as race, class, gender, age, geography do play a role in the dimension of application in Biblical interpretation but only on the basis of the dominant heuristic keys of the group. The choice of heuristic keys is largely influenced by the group's ecclesial tradition. [5]

- Bible study groups, not surprisingly, remain largely unaware of a range of possible ideological distortions in their reconstructions of the text, their own ecclesial traditions, their interpretative "world", and the broader contexts within which they live. [6]

- The interaction among group members is often aimed at reinforcing, clarifying and elucidating the beliefs, practices and purposes of the group. The categories of insiders (insiders within and outsiders within) and outsiders (insiders outside and outsiders outside) may be helpful to analyse this interaction. ${ }^{10}$ Some insiders may also become

9. See the contribution by Conradie on "Biblical interpretation within established Bible study groups" elsewhere in this volume.

10. See the contribution by Conradie on "Biblical interpretation within established Bible study groups" elsewhere in this volume. 
discontented with the dominant tendency for confirmation of existing beliefs, especially if their expectations include a strong element of growth. [7]

The following research procedures were established in order to test and develop these hypotheses through empirical research.

a) Six of the Bible study groups that participated in the pilot project were again approached to participate in the new project. Since some of these groups ceased to exist since the pilot project, new ones had to be identified. Again these groups were selected from as many different backgrounds as possible, taking gender, race, class, age and ecclesial traditions into account. The following six groups participated in the new project: ${ }^{11}$

- Sokhanya Bible School: A Xhosa speaking group of church leaders from the African Indigenous Churches in Khayalitsha. As a Bible school the focus of this group is on Bible study itself (This applies to all the other groups only to a lesser extent).

- Ottery group: A Bible study and support group of elderly women from the Dutch Reformed Church. The group functions within a predominantly lower middle class neighbourhood.

- Langa Baptist group: A relatively large Xhosa speaking youth group from the Baptist church in Langa. The group includes a number of students and young black professionals.

- Strand Anglican group: A recently established Bible study group from the Anglican parish in the Strand. The group has a multi-racial composition.

- Lighthouse group: A Pentecostal Bible study and prayer group based in Belhar and related to the Lighthouse (a large Pentecostal church in Cape Town).

- Belhar Anglican group: A well-established Bible study and prayer group from the Anglican parish in Belhar.

b) In a letter of invitation the groups were asked to read two Biblical texts, i.e. Matthew 13:53-58 and Luke 4:16-22, 28-30 in two Bible study sessions. In the first session they were requested to "Read the text in the way you normally do it." Intervention was therefore limited as far as possible. In the second session each of the six groups was provided by the research team with some input (informative, critical or questioning) on one of the first six factors playing a role in group Bible studies as identified in the pilot project (see above). Each group was provided with input on a different aspect of interpretation. ${ }^{12}$ The purpose of providing this input was not so much to provide some background to assist the Bible study group but to test the way in which a particular factor influences group Bible study.

c) Permission was asked from each group to make a video recording of each Bible study event. This was done through the help of several research assistants (Graham Thorne, Xolani Sakuba, Franziska Andrag and Lutasha Abrahams). Xolani Sakuba was also responsible to translate the Bible study events of the Sokhanya and Langa groups.

11. The Stellenbosch Sentraal group also participated in the project. Unfortunately, the tape recordings of the two Bible study events of this group were of such a bad quality that this could not be used for discussion and analysis.

12. For detail on the input that was provided to each group, see the various analyses of the Bible study events elsewhere in this volume. 


\section{The completion of the project during 2000 and 2001}

During 2000 and 2001 slow but steady progress was made with the organisation, recording and analysis of the 12 Bible study events (with 6 groups doing two Bible studies each). The video recording of each session was viewed, discussed and analysed in some detail by the research group over a period of two years. ${ }^{13}$ The purpose of this rather painstaking process was not in the first place to test the research hypotheses as stated above but to provide a "thick description" of each Bible study event. Such a thick description had to describe the main thrust of the way in which the particular group read and interpreted the particular text. The question was therefore not how the various readings may be evaluated or compared with one another. Instead, the question was whether the group would be able to recognise themselves in the description. Nevertheless, the descriptive and evaluative instrument that was developed during the pilot project was used where appropriate.

The various thick descriptions on each of the Bible study groups are included in this edition of Scriptura. On the basis of these thick descriptions, Conradie and Jonker reflected on the validity of the research hypotheses as stated above. The results of these reflections are also included in this volume. ${ }^{14}$

\section{New questions that emerged and the way ahead}

The discussion of the empirical data during the project described above prompted several new questions. These questions were prompted by the responses of the various groups to the inputs that were provided to them for the second Bible study on Luke 4. In most cases, it was quite clear that the groups experienced these inputs to be more of a hindrance than an aid to Bible study. This raised a number of important questions. What kind of contribution(s), if any, can trained readers make to facilitate group Bible study? In what ways and in which format should these inputs be made available to established Bible study groups? How does one respect the integrity and identity of a group, prevent a dependency on outside expertise (which far too many popular Bible study guides do not avoid), stimulate a self-critical mode of reading the Bible and contribute to relative adequacy in Biblical interpretation?

These questions may require further reflection on the interaction between trained readers and established Bible study groups. This will require not only theoretical but also empirical research on the various ways in which trained and ordinary readers of the Bible relate to one another.

As indicated above, the original research project envisaged an operational component that could develop a pedagogical instrument to facilitate adequacy in the context of group Bible study. As a result of the response of the groups to the inputs that were provided, the research team decided not to proceed with the development of such a pedagogical instrument.

The project will in this sense remain incomplete. With the completion of this pilot and the second phase of the research project we may be able to understand the complex dynamics of group Bible study somewhat better. However, this does not imply that we know how to help groups to read and interpret the Bible better. Further research is required to understand how adequacy in Biblical interpretation within established Bible study groups may be enhanced.

13. The group included the following members: Ernst Conradie \& Douglas Lawrie (UWC), Hendrik Bosman and Louis Jonker (US), Chuck Wanamaker (UCT) and Danie van Zyl (Sokhanya Bible School) as well as four research assistants, i.e. Graham Thorne, Xolani Sakuba, Franziska Andrag-Meyer and Lutasha Abrahams.

14. See the contribution by Conradie \& Jonker in this regard. 


\title{
A 'THICK DESCRIPTION' OF TWO BIBLE STUDIES BY THE DUTCH REFORMED CHURCH OTTERY GROUP
}

\author{
Louis C Jonker \\ Department of Old Testament and New Testament \\ Stellenbosch University
}

\section{The profile of the group}

The group consists of more or less 20 Afrikaans speaking women from a lower-middle class neighbourhood in Ottery. They are all members of the Dutch Reformed Church, and most of them are retired pensioners. The local pastor functions as the group leader. They live in a suburb of Cape Town where dramatic population changes have taken place over the past ten years. The area now has a multiracial population (mainly coloureds and whites), and several of the "new" inhabitants are Muslims. Although racial and religious tensions may well be present, the group members commented on the good relationships between neighbours that exist in their area. Many of them trust these "others", and the occasional friendship is also starting to develop.

\section{Self-identification of group}

In terms of the group's self-understanding, it meets for especially two purposes: On the one hand, they are there to care for one another and to support one another. They pray for those members who are sick and lonely, and they encourage one another. One member even said that she missed the group during the long holidays. On the other hand, they all have the desire to "understand" the Bible better. They want to deepen their knowledge of the Bible. They trust that this will help them to grow in their faith.

\section{Procedure}

Two Bible study sessions were held. During the first session the group read Matt. 13:53-58 without any input from the research group. They were asked to proceed in the way they would normally do during their Bible study meetings. During the second session on Luke 4:14-24 the group was provided with some input from the research group that focussed the attention of the group on the text itself, and its literary and intra-textual relationship with the Matthew parallel. The following input was provided to the group leader who assimilated this input through the questions that he put to the group:

You may have noticed that the text in Luke 4:14-24 refers to the same incident that we discussed in last week's meeting from Matthew 13:53-58, i.e. the response to Jesus from within his home town of Nazareth. The way in which the incident is framed is quite different though. Can you pick up the differences? Which elements do the two versions have in common? What would you say is the particular emphasis of Luke's version? Why would the people of Nazareth be so angry with Jesus that they would try to kill him (verse 28-29)?

\section{Bible study 1: Matthew 13:53-58}

The group started off with by introducing each group member. The pastor then asked the members: "Where do you normally go for holiday?" Their answers led to the next question: "When you are with family members, what is your experience when you talk to them about issues of faith?" Some responded that they sometimes feel rejected by some of their family members. 
The pastor then asked the group members to identify those aspects of the text that seem to be important to them. They agreed that it is astonishing that the people of Nazareth did not believe in Jesus, although he was one of them. They did not realise that he was the Son of God. Therefore his identity and authority was doubted. The group then reflected for a moment on the question whether they would have believed in Jesus if they were living in those days. Many agreed that they would not have reacted differently from those people of Nazareth.

The pastor after that offered an exposition of the literary context in which this narrative is situated. He indicated that the parable of the sower in chapter 13:1ff, in contrast to the three parables about the kingdom of heaven in 13:44ff, shows that there are people who are initially impressed by the words of Jesus, but who do not come to faith in Jesus. He showed how the pericope under discussion relates to the parable. This prompted the group to identify with the people of Nazareth. "We are often like those people", they responded. The pastor also focussed the attention on the narrative following chapter 13 where the disciples in the boat declared: "You are surely the Son of God." The issue of belief in Jesus as the Son of God (who is regarded by the people of Nazareth simply as a local resident) reaches a climax in chapter 14.

The pastor followed this up with a next question: "What is the message of this narrative for us today?" This question brought them back to reflect on their own authority as witnesses among their family members. They should not refrain from witnessing about their faith, despite the opposition that they may encounter from their "own" people. They then identified the meaning of this text for us today in the following way: "We should believe without seeing. We should not evaluate someone on external appearances. We should believe in Jesus without him doing miracles. God has his own time and space."

\section{Bible study 2: Luke 4:16-22, 28-30}

This Bible study started with the following question that the pastor raised: "What is the message of this text for us today?" The group highlighted the fact that the text says that Jesus came to the oppressed, the poor and the captives. That means that he did not come in the first place to affluent people. They also noted that Jesus quoted from the Book of Isaiah. Thereafter they were asked to indicate which parts are unclear to them. They did not understand why the people of Nazareth did not accept Jesus, and they had questions on Jesus' reference to Naaman the Syrian. Did he believe more strongly?

The pastor then led them to reflect on the message of the text for today. Someone responded: "We should have faith without seeing." Someone else reacted sceptically with reference to some of the great faith healers that impress people with their so-called miracles.

After this introductory discussion the pastor provided the group with some information regarding the historical background of the text. He explained that this text forms a synoptic parallel to the text in Matthew that was discussed during the previous meeting. The group was led to discover that the literary context of Luke differed from that of Matthew: the narrative occurs at the beginning of Jesus' public ministry and as an "inaugural sermon". The reason for the differences is that Luke did more research on the life of Jesus, and that the different gospels focused on different issues. Because this is presented as the inaugural sermon of Jesus, it becomes clear from the start that Jesus did not come to the earth for rich people, but for the poor. This sermon is therefore programmatic for his public ministry.

In the next stage of the Bible study the group reflected on the reference to Isaiah 61 . The group leader indicated that Jesus did not quote the text in full, but that he truncated the 
reference to divine punishment. The reference to Isaiah 61 shows that Jesus not only came to his own people, but to all the nations.

Leviticus 25 was then read to show where the law on the year of grace is described in the Old Testament. The reason for this institution was to help the poor not to be trapped in poverty forever. The law aimed at equalizing the rich and the poor in society. For a moment the group pondered on the issue of land, and how people still today (and in the South African context) tend to quarrel about land ownership. Luke 4 shows that the law on the jubilee year was fulfilled in Jesus. In his ministry Jesus came to the poor to lift them up and to make them equal to the rich.

In the next (application) phase of the Bible study, the group leader again asked what the message of the text is for us today, and how it may influence the role of the Dutch Reformed Church in society. Some of the responses were: "We should also grant our neighbours opportunities in life. We should focus on Jesus Christ. We should act accordingly towards our fellow human beings." When the group was asked what they have learnt from this study, they were in agreement that the text is all about God's great love for us as sinners.

\section{Comments}

1. The local pastor influences the group dynamics considerably. The group assumes the authority of the pastor who acts as group leader to pose appropriate questions that will enable them to grasp the meaning of the text, and to decide on the (in)correctness of their responses. The reading strategy of this group is therefore strongly influenced by the pastor's input. However, because this group has been in existence for many years, and because the pastor leads the group every week, this style has also become the way in which the group members deal with Biblical texts. The size of the group, its ethos and group dynamics resulted in only a few members (more or less five) taking part in the discussions. The others attend the meetings every week, but seldom speak during the meeting, except when they are asked to read a verse from the Bible. Their continued presence nevertheless indicates that they find the insights gained to be valuable for their faith and everyday life.

2. According to the self-understanding of this group they come to the Bible study meetings to do exactly that, namely to study the text of the Bible. Although the pastor leads them to analyse the text itself as meticulously as possible, it seems, however, that they are not able to assimilate their knowledge about the text into their interpretation. This was especially obvious in the second session. The pastor normally leads them to pay attention to the broader literary contexts and the way in which those contexts influence the understanding of the text under discussion. In the first session it was, for example pointed out that the parables of the sower and of the kingdom of heaven in Matthew 13, as well as the confession by the disciples in chapter 14 that Jesus is truly the Son of God, should be seen as the backdrop against which the present account of Jesus in Nazareth should be understood. The literary context therefore indicates that there are people who hear the Word, but who soon forget it again. This was linked to the unbelief of the people of Nazareth. The confession in chapter 14 was related to the argument about Jesus' authority in Nazareth. With these comments, the literary context and the rhetorical structure of the text as a whole were clarified by the pastor

In the second session the leader provided the group with some input on the synoptic parallel in Matthew. This input was noted by the group, although the members could not really elaborate on the difference of emphasis in the two synoptic parallels. They even 
complained at the end that the questions were a bit too difficult for them. It was emphasised by the leader that the Lukan parallel puts this text at the beginning of the public ministry of Jesus. In a way Luke presents this as Jesus' inaugural sermon. The leader also asked the group to pay attention to the Old Testament references in this text. The group therefore also read Isaiah 61 (the direct reference in Luke 4) and Leviticus 25 (the theme of the year of grace). It was indicated that Jesus left out some significant parts of the text of Isaiah 61. Jesus mentions nothing about punishment, because (according to the group) he has already come to pay all debts.

3. The group did not pay much attention to the world behind the text. However, one group member mentioned a few times that Luke's version differs from that of Matthew, because Luke has used Matthew and Mark, and that Luke did more research on the life of Jesus. His description is therefore more in depth.

Furthermore, the leader (and some of the members) indicated that Jesus gave special attention to the "not so rich" and marginalized people in society. The fact that Jesus quotes from Isaiah 61 indicated to the group that Jesus did not come for rich people in the first place. The reference in Luke 4 to the widow of Sarphat and Naaman the Syrian, also stimulated the curiosity of the group members. They wanted to know who those people were, and why Jesus mentioned them.

4. Although the doctrinal keys used by the group are heavily influenced by their theological tradition, they do not give any indication that they are aware of the influence of this tradition on them. Their self-understanding is merely that they are Christians, and that they live in an evil world where there is so much unbelief, and that they differ from their neighbours who are Muslims. It is clear, however, that the codes or keys that they use to unlock meaning from the text are strongly influenced by the reformed theological tradition from which they come from. "To believe" forms a key concept in their understanding: One has to believe in Jesus without seeing him. One should believe in him even if he does no miracles. Our belief in Jesus begins with the acceptance of his authority as the Son of God. We should not judge him (or other people) superficially ("Jy moenie iemand op die baadjie takseer nie"). It is not the spectacular that should encourage us to believe. Jesus comes as a normal person, as one of the locals, and, although it is more difficult, we should recognise him to be the Messiah. From this the group gathered that Jesus shows great love for sinners.

5. The group used different interpretative strategies. In the first place they tried to identify some abiding truths in these texts. What does it say about people believing or not believing in Jesus? Those who believe are those who accept the authority of Jesus. Those who do not belief in Him, restricts his ability / will to do miracles. Some people are indeed impressed by the words of Jesus, but they do not act accordingly (as the parable of the sower shows). What Jesus wants from us as believers is to confess that $\mathrm{He}$ is the Son of God (as the disciples did).

Furthermore, the group members view their experiences as believers to be a sequel to the encounter of Jesus with his own people. This strategy operates on two levels: On the one hand they identify certain parallel relationships, and (closely associated with these relationships) they associate with different characters in the story.

On the level of parallel relationships, they also often struggle with their own people (even family members) who do not believe in Jesus, and they even have difficulty in witnessing to these people. The relationship of Jesus with the (unbelief of) the people of his hometown, corresponds to their own relationship with people who do not believe. Additionally, the relationship of Jesus to poorer people (indicated by the Lukan text) 
corresponds to his relationship to them who are also "not so rich". This understanding strengthens and comforts them.

On the level of association with some or other of the characters, it is clear that the group identifies both with Jesus and the people of the town. Jesus is the one struggling to be recognised, and he opposes those who do not accept his authority (as they do in their society). However, they doubt whether they would have reacted differently from the people of Nazareth. In the Lukan version they also (although not too explicitly) identify with the "poor" or "not so rich" to whom Jesus has given special attention.

Exactly because of their experience that Jesus also sees and values them, they find their lives to be a further fulfilment of the promises of Jesus. They can depend on him to be there for them, as He has announced in his inaugural sermon in Nazareth.

6. It is not clear whether the Bible study has any praxeological effect in this group. The Bible study rather leads to an affirmation of their own beliefs, and comforts them as people who are recognised by Jesus. It helps them to draw the lines between themselves and non-believers clearer. It also inspires them to act in a friendlier way towards their neighbours who are not Christians.

7. The group has a literary reading attitude with the conviction that Scripture can best be interpreted in the light of other parts of Scripture. This reformed axiom plays an important role in their understanding of the Bible. Furthermore, there is no doubt that the Bible is the Word of God for us for today, and that it can be read for contemplation, for personal edification, and as a means of survival in their own situation.

8. The group gives some indications that they are aware that their contemporary context influences their reading. It has already been mentioned above that they are quite aware of the fact that they live in "new" conditions in a multi-cultural and multi-religious neighbourhood. When they read the text from Leviticus 25 about the jubilee year, someone remarked that this could help us also in the New South Africa where people are quarrelling about land. It will also help to wipe out the differences between rich and poor.

9. The group seems to be unaware of any ideologies or power relations that may orientate, influence, guide or distort their interpretation of these texts. Although they give attention to the fact that Jesus came for the poor, and although this truth obviously comforts and strengthens them, they are not aware of the fact that they differ in their reading from other people coming from other parts of society. 